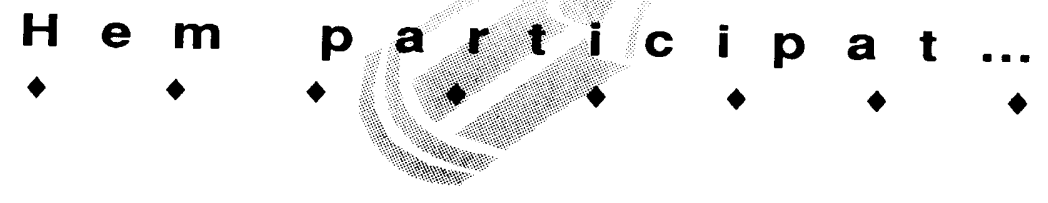

Entre els ponents vam comptar amb la participació de personalitats de prestigi internacional com Salvador Giner, Juan Linz, Enrique Cardoso, Carlota Solé, Ignacio Sotelo i Amando de Miguel, entre d'altres.

Dos professors de la nostra Facultat (Aurora Aubach i Saturnino Menchón) hi vam participar activament aportant-hi sengles treballs: “lgualdad para las mujeres, ¿cuándo?" i "La Interacción multicultural en el aula", respectivament.

Aurora Aubach i Guiu

Saturnino Menchón García

\section{ENCUENTROS DE DIDÁCTICA DE LAS CIENCIAS EXPERIMENTALES}

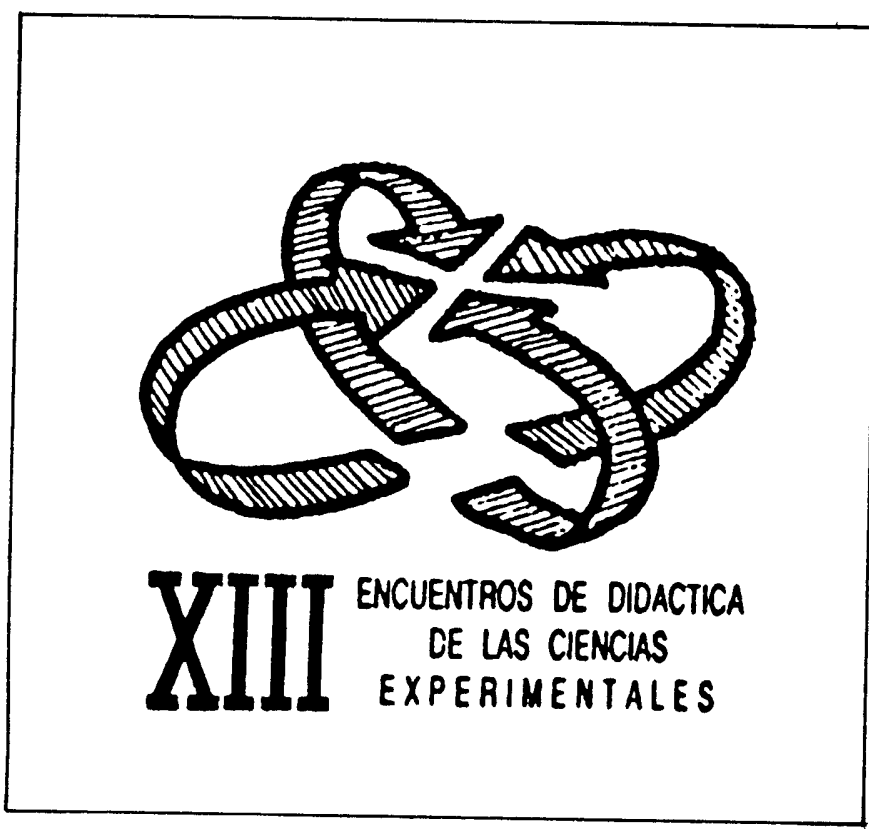

Com ja és habitual des de fa tretze anys, al mes de setembre se celebrà, a l'Escola Universitària de Formació del Professorat d'E.G.B. de Guadalajara, la reunió anual del professorat que imparteix docència de Ciències Experimentals a les Escoles de Mestres i Facultats d'Educació.

Durant cinc dies (21-25 de setembre del 1992), en sessions de mati i tarda, s'exposaren una seixantena de comunicacions, ja sigui en forma oral, de póster, o de taller, una dotzena de les quals foren presentades per professors de l'àrea de Didàctica de les Ciències Experimentals del nostre departament.
Els Encuentros, aquesta vegada inclosos dins els actes celebrats amb motiu del 150e. anniversari de la fundació de l'Escola de Guadalajara, tingueren la seu a l'edifici del mateix centre. L'acte inaugural, que es realitzà al saló d'actes, comptà amb la presència de les autoritats acadèmiques $i$ administratives. Acte seguit, el professor anglès Charles Ryan pronuncià la conferència: Aproximación a la enseñanza de las ciencias en Educación Primaria: algunas innovaciones. Es clogué l'acte amb un vi espanyol ofert per l'Escola a tots els assistents.

Entre les sessions s'hi intercalà una xerrada, força didàctica, a càrrec del Dr. Pere Planesas, astrofísic de l'observatori de Yebes, titulada: Sugerencias prácticas para la enseñanza de la Astronomía, que fou vivament aplaudida per la concurrència.

Els assistents inscrits als Encuentros procedien de diverses províncies espanyoles. Aixi, n'hi havia d'Alacant, Almeria, Asturies, Àvila, Barcelona, Bilbao, Castelló, Ciudad Real, Girona, Granada, Guadalajara, Jaén, La Laguna, Lleó, Madrid, Melilla, Múrcia, Orense, Oviedo, Sevilla, Soria, Tarragona, Terol, València, Valladolid i Zamora.

Comentari a part es mereix l'acollida dispensada per la ciutat als Encuentros. La visita al magnífic edifici de la Diputació, així com a l'Ajuntament, on fórem rebuts per la pràctica totalitat de la corporació municipal; la visita al conjunt monumental i históric de la ciutat, amablement guiats per professores de l'Escola; la visita a la fábrica de vidre d'Azuqueca i a l'observatori astronòmic de Yebes; l'itinerari geològic, de la mà dels professors de Geologia del centre, i l'excursió a Sigüenza —on apreciàrem la bellesa de la seva catedrał- i al romànic rural de Saúca i Jodra, deixaren un record inoblidable a tots els qui participàrem als XIII Encuentros.

Pel que s'ha dit, la reunió fou un exit. I tot gràcies als esforços dels components de les àrees de Ciències, M Teresa Fernández-Galiano Ruiz, José F. GarcíaHidalgo Pallares, $M^{a}$ Dolores Molina Navas, Manuel Segura Redondo, Eloísa Vivas Arce, $\mathrm{M}^{\mathrm{a}}$ Puy Zugasti Arbizu i, especialment, als d'Amelia Calonge García, que, en tot moment, fou l'ànima de la reunió. Gràcies a tots.

Agustí Salvat Altés 